\title{
KOMUNIKASI EFEKTIF: AKTUALISASI KOMPETENSI SOSIAL GURU DALAM PERSPEKTIF ISLAM
}

\author{
Elvian Mutiara $^{1}$, Eva Zulvi $^{4}$, Shella Masrofah ${ }^{3}$, Difa Ul Husna ${ }^{4}$ \\ Universitas Ahmad Dahlan Yogyakarta \\ e-mail: 1elvian1900031173@webmail.uad.ac.id, 2Difaul.husna@pai.uad.ac.id, \\ 3eva1900031208@webmail.uad.ac.id,.4shella1900031202@webmail.uad.ac.id
}

\begin{abstract}
Social competence is the competencies that must be possessed by a teachers or educator. The existence of investigating this social competence aims to reveal again about effective communication carried out by teachers with students or the community as a form of actualization of teacher competencies in an Islamic perspective. The method used in this research is in the form of qualitative analysis with a library research approach or library method. Social competence can be interpreted as a teacher's performance in speaking and communicating with students, fellow teachers, and with sorrounding community in an effective and interactive manner. A teacher must have good social competence in carrying out their duties and roles. Without good communication skill, of course the implementation of education process and daily life will not run effectively and not as expected. Teacher social competence is divided into two, namely: teachers in the school environment and teachers in the community. If a teacher can develop their social competence, it will be easier to carry out their duties and responsibilities. Effective communication will be created from a teacher who has good social competence.
\end{abstract}

Keywords: communication; social competence; islamic perspective.

\begin{abstract}
Abstrak
Kompetensi sosial adalah salah satu kompetensi yang harus dimiliki oleh seorang guru atau pendidik. Adanya penelitian mengenai kompetensi sosial ini bertujuan untuk mengungkap kembali mengenai komunikasi efektif yang dilakukan guru dengan peserta didik ataupun masyarakat sebagai bentuk aktualisasi kompetensi guru dalam perspektif islam. Metode yang digunakan dalam penelitian ini yakni berupa analisi kualitatif dengan pendekatan library research atau metode kepustakaan. Kompetensi sosial dapat diartikan sebagai suatu kinerja guru dalam bercakap, dan berkomunikasi dengan para peserta didik, sesama pendidik, maupun dengan masyarakat sekitar secara efektif dan interaktif. Seorang guru harus memiliki kompetensi sosial yang baik dalam menjalankan tugas dan perannya. Tanpa adanya kemampuan komunikasi yang mumpuni, tentu pelaksanaan proses pendidikan dan berkehidupan sehari-hari tidak akan berjalan efektif dan tidak sesuai dengan yang diharapkan. Kompetensi sosial guru dibagi menjadi dua, antara lain: guru dalam lingkungan sekolah dan guru dalam bermasyarakat. Jika seorang guru dapat mengembangkan kompetensi sosialnya, maka akan lebih mudah dalam menjalankan tugas dan tanggung jawab. Komunikasi yang efektif akan tercipta dari seorang guru yang memiliki kompetensi sosial yang baik.
\end{abstract}

Kata kunci: komunikasi; kompetensi sosial; prespektif islam.

\section{PENDAHULUAN}

Hubungan sosial dalam bermasyarakat sangatlah diperlukan, sebab manusia ialah makhluk yang saling membutuhkan dan tidak mampu mengatasi semua permasalahan hidup dengan sendirinya. Menjalankan hubungan sosial perlu adanya 
komunikasi. Komunikasi merupakan suatu interaksi yang dilakukan seseorang kepada lainya guna memberitahu atau menginfokan sesuatu. Selain dalam bermasyarakat, dalam dunia pendidikan juga perlu adanya komunikasi. Komunikasi pendidikan ialah interaksi guru dengan peserta didik pada proses pembelajaran guna mencapai suatu tujuan pendidikan. Dunia pendidikan juga memiliki hubungan dalam bermasyarakat. Jika masyarakat tidak mengetahui pentingnya pendidikan maka lembaga pendidikan tidak akan berfungsi semestinya. Salah satu pemegang peran penting dalam hal ini ialah guru atau pendidik. Guru diharapkan bukan hanya bisa bergaul dan berkomunikasi dengan peserta didik namun juga dengan masyarakat. Seorang pendidik harus memiliki beberapa kompetensi dalam meningkatkan proses pembelajaran, salah satunya yakni kompetensi sosial. Kompetensi sosial guru berarti kemampuan serta kinerja seorang guru dalam melakukan komunikasi dengan orang lain secara efektif dalam proses pembelajaran (Ashsiddiqi, M. Hasbi; 2012). Kompetensi ini sangat penting dimiliki guru, sebab guru merupakan masyarakat sosial dan masyarakat juga bagian dari salah satu komponen pendidikan. Maka profesinya di bidang pendidikan sangat berpengaruh bagi masyarakat (Muspiroh, Noviyanti; 2016).

Jika kita lihat di zaman ini, guru dituntut untuk bisa melakukan segala hal. Baik yang berkaitan dengan dunia pendidikan ataupun tidak. Baik yang ada di dalam kelas ataupun di luar kelas. Peran guru tidak hanya di depan peserta didiknya saja, tetapi juga dengan masyarakat luas. Peran guru yang harus menjaga hubungan baik dengan masyarakat dan juga wali murid agar selalu mendapat dukungan dan kepercayaan dari mereka dalam melaksanakan tugas sebagai seorang pendidik yang akan menjaga dan mendidik para generasi bangsa. Ada banyak permasalahan yang dihadapi guru zaman modern, ditambah kondisi pandemi saat ini yang mengharuskan semua guru mengajar dari rumah atau secara daring. Guru dituntut untuk bisa menggunakan teknologi dengan baik, agar proses pembelajaran tetap berjalan lancar dan sesuai rencana. Adapun kasus yang terjadi pada saat proses pembelajaran daring berlangsung, seperti dikutip dari liputan 6 (Liputan6.com. (2020, 4 November). Diakses pada 11 november 2020, bahwa "Survei P\&G: 85 Persen Orangtua dan Anak Indonesia Terkendala dalam Pembelajaran Daring" dijelaskan bahwa pada era digital ini semua orang dari berbagai kalangan harus mampu beradaptasi dengan teknologi untuk melakukan segala aktivitasnya, termasuk dalam melaksanakan suatu proses pembelajaran. Namun faktanya tidaklah mudah bagi peserta didik untuk beradaptasi dengan keadaan tersebut. Berdasarkan survei yang dilakukan $\mathrm{P} \& \mathrm{G}$, terdapat sekitar 85 persen peserta didik maupun orang tua yang 
mengalami kesulitan dalam melaksanakan pembelajaran virtual. Bahkan beberapa orang tua mengaku tidak mempunyai fasilitas yang cukup untuk melakukan proses pembelajaran sang anak. Melihat Kasus seperti ini, maka guru harus bisa memberikan solusi dan informasi secara tepat dan cepat agar dapat membantu mempermudah para orang tua saat mendampingi anaknya ketika belajar secara daring. Jika guru tidak dapat memberikan informasi secara tepat kepada peserta didik, maka proses pembelajaran tidak akan berjalan lancar.

Selain itu, kasus yang dikutip dari okezone (okezone.com. (2020, 22 agustus). Apakah Pembelajaran Daring Bembuat Anak Menjadi Anti-Sosial? Dalam kutipan di atas dijelaskan tentang adanya kekhawatiran orang tua peserta didik kepada anak-anaknya, yang membuat mereka menjadi anti sosial dan kurang pergaualan akibat pelaksanaan sekolah online atau daring. Pasalnya, pelaksanaan sekolah online ini tidak mendorong para peserta didik untuk melakukan interaksi dan tatap muka dengan guru ataupun dengan peserta didik lainnya secara langsung.

Permasalahan tersebut dapat memicu adanya perilaku anti sosial yang diakibatkan oleh kurang efektifnya komunikasi dan interaksi yang dilakukan oleh peserta didik. Pada permasalahan ini, peran guru sangat diperlukan untuk memberikan solusi yang tepat agar menjauhkan peserta didik dari perilaku anti sosial. Guru dituntut untuk solutif terhadap segala kondisi yang harus dihadapi agar proses komunikasi maupun interaksi dengan peserta didik maupun dengan sesama pendidik tetap berjalan secara efektif meskipun penerapannya di masa pandemi ini kurang maksimal.

Sesuai penelitian yang pernah dilakukan oleh (Huda, Mohammad Nurul; 2018) kompetensi sosial guru dapat dilihat melalui beberapa indikator, Pertama hubungan antara guru dengan para peserta didik. Pembahasan indikator hubungan guru dengan para peserta didik menjelaskan bahwa seorang guru harus mampu menjadi suritauladan yang baik untuk para peserta didiknya dengan cara memberikan kasih sayang, keadilan, dan melaksanakan tugasnya sebagai seorang guru yang bertanggung jawab serta tidak serta merta karena adanya bayaran yang diterimanya. Kedua hubungan guru dengan guru lainnya. Pembahasan indikator ini menjelaskan bahwa seorang guru harus menciptakan iklim kerja yang baik antar guru lainnya. Iklim meliputi kebudayaan sekolah, tradisi sekolah, dan juga sikap personalia yang ditunjukkan oleh pribadi seorang guru. Ketiga hubungan guru dengan para wali murid. Indikator ini membahas tentang hubungan antara guru dengan wali murid harus baik dan ada timbal baliknya. Sehingga di antara keduanya bisa bekerja sama untuk mengatasi permasalahan di sekolah dan pribadi anak. Keempat 
hubungan guru dengan masyarakat luas. Indikator ini menjelaskan bahwa seorang guru juga ikut serta memikul tanggung jawab dalam memajukan, mengembangkan serta menjaga persatuan dan kesatuan bangsa juga mensukseskan pembangunan sosial.

Beberapa kasus yang berpotensi muncul pada proses komunikasi atau miscommunication pembelajaran daring, mengharuskan guru agar bertindak cepat dan tepat untuk memberikan informasi secara jelas, baik dan tepat kepada peserta didik maupun wali murid. Selain membantu para siswa belajar secara daring, guru juga harus bisa membantu masyarakat sekitar mempermudah proses pembelajaran para peserta didik ketika di rumah. Salah satu cara yang dapat dilakukan melalui sosialisasi mengenai pemebelajaran daring kepada masyarakat sekitar. Guru dapat memberikan informasi terkait pembelajaran daring. Baik sistem pembelajaran, kurikulum, pemberian tugas, penilaian dan lain sebagainya. Sehingga para orang tua peserta didik paham dan mudah dalam memberikan arahan kepada sang anak dalam proses pembelajaran daring berlangsung. Dengan demikian, seorang guru perlu memiliki dan meningkatkan kompetensi sosial pada dirinya.

Indikator-indikator dalam kompetensi sosial yang telah disebutkan di atas sangatlah penting untuk dikuasai oleh seorang pendidik. Pada kenyataannya, sosok guru menjadi seseorang yang dikagumi, dicontoh dan diteladani perilaku baiknya oleh peserta didik hingga masyarakat. Seorang guru yang profesional tentunya akan melaksanakan tugas dengan sebaik-baiknya dan tidak melanggar garis larangan untuk dilakukannya. Seperti yang dilakukan ketika berada di lingkungan sekolah, hubungan dengan sesama guru adalah saling memberikan dukungan dan menjaga hubungan yang baik. Begitu juga yang harus dilakukan dengan wali murid maupun masyarakat, perlu bagi seorang guru untuk menjaga komunikasi serta interaksi dengan cara menghormati dan menjaga hubungan baik dengan mereka. Jika semua indikator tersebut dapat diterapkannya, maka tujuan pembelajaran akan dapat dicapai dengan mudah.

Tidak dapat dipungkiri, begitu banyaknya problematika yang dihadapi dalam proses belajar mengajar di zaman modern ini. Kurangnya komunikasi yang terjalin antara guru dengan sesama guru, guru dengan para peserta didik, bahkan antara guru dengan wali murid sangat berakibat bagi keberhasilan belajar peserta didik tersebut. Adanya permasalahan tersebut, perlu peninjauan ulang terkait cara guru dalam berinteraksi maupun dalam menggunakan komunikasi yang baik dan efektif dengan sesama pendidik, peserta didik, wali murid, maupun dengan warga sekitar. Berdasarkan uraian di atas, penelitian ini memuat pembahasan mengenai komunikasi dan kompetensi sosial guru 
dalam perspektif Islam.

\section{METODE PENELITIAN}

Penelitian ini menggukan metode analisis deskriptif kualitatif. Pendekatan yang digunakan ialah pendekatan library research atau metode kepustakaan. Metode kepustakaan adalah metode yang menggunakan pengumpulan data. Metode kepustakaan ini dilakukan dengan cara mengumpulkan beberapa bahan bacaan yang bersumber dari buku referensi, jurnal-jurnal, dan beberapa bahan ajar. Adapun cara pengumpulan datanya melalui kajian keputakaan sesuai dengan masalah yang akan diteliti, jika statistics-facts telah diperoleh kemudian mencatat poin penting pada buku catatan disiapkan. Selanjutnya, dengan menggunakan metode deskriptif data tersebut dianalisis sesuai permasalahan yang diteliti. Adapun tujuan dari peenlitian ini adalah untuk mengungkap kembali mengenai komunikasi efektif sebagai bentuk aktualisasi kompetensi guru dalam perpsekttif Islam.

\section{HASIL DAN PEMBAHASAN}

Berkaiatan dengan hal tersebut Standar Nasional Pendidikan Pasal 28 ayat 3 butir d menjelaskan bahwa kompetensi sosial adalah kemampuan guru sebagai bagian dari masyarakat untuk berkomunikasi dan bergaul secara efektif dengan peserta didik, sesama pendidik, tenaga kependidikan, orang tua atau wali peserta didik, dan masyarakat sekitar. Menurut (Suparman, Oman; 2020). Kompetensi sosial guru adalah kemampuan dan kecakapan seorang guru dalam berkomunikasi dan berinteraksi secara efektif pada pelaksanaan proses pembelajaran serta masyarakat sekitar. Hal di atas dapat digaris bawahi bahwa kompetensi sosial ialah kemampuan guru dalam bercakap, berinteraksi atau berkomunikasi dengan peserta didik, guru lainnya, maupun dengan masyarakat sekitar secara efektif dan interaktif. Sebagai pribadi pendidik, seorang guru harus mampu berbaur dengan masyarakarat sekitar agar hubungan antara guru, peserta didik dan masyarakat terjalin dengan baik pula. Bila seorang guru mampu menguasai kompetensi sosial dengan baik, maka peserta didik akan turut meneladani sikap tersebut. Sebab peserta didik bukan hanya membutuhkan kecerdasan intelektual, emosional, dan spiritual dalam berkehidupan, tapi juga memerlukan kecerdasan sosial. Tujuannya supaya peserta didik memiliki rasa tanggungjawab, kekeluargaan, serta rasa peduli akan sesama. ditambah lagi rasa saling menghormati dan menghargai sehingga tercipta hubungan yang harmonis, rukun dan damai tanpa adanya pandangan perbedaan. Sebagaimana firman Allah SWT : 


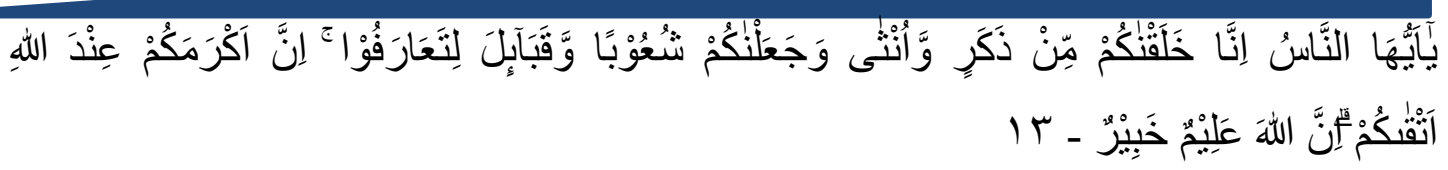

\begin{abstract}
"Wahai manusia! Sungguh, Kami telah menciptakan kamu dari seorang laki-laki dan seorang perempuan, kemudian Kami jadikan kamu berbangsa-bangsa dan bersuku-suku agar kamu saling mengenal. Sesungguhnya yang paling mulia di antara kamu di sisi Allah ialah orang yang paling bertakwa. Sungguh, Allah Maha Mengetahui, Mahateliti”
\end{abstract}

Dari ayat di atas dapat dijelaskan bahwa menurut (Chalik, S. A; 2015) Allah secara tegas menggambarkan bahwa manusia tidak diciptakan dalam satu kesamaan. Dengan adanya perbedaan antara satu dengan lainnya, justru saling melengkapi. Sekiranya manusia diciptakan sama dalam hal kecakapan, kecenderungan, kekayaan atau lainnya, maka setiap orang akan memiliki kualitas yang sama. Akibatnya, orang tidak akan saling memerlukan sehingga kerjasama pun tidak mungkin terjadi, dinamika masyarakat tidak ada, bahkan masyarakat yang harmonis dan sejahtera tidak akan terwujud.

Oleh karena itu adanya hubungan sosial sangat diperlukan. Allah SWT sangat senang kepada hambanya yang mau menjalin hubungan silaturahmi kepada sesama. Allah SWT tidak menyukai orang yang memutuskan hubungan silaturahmi antar sesama, apalagi jika itu adalah keluarga, kerabat ataupun saudara. Sebab menjalin dan menjaga hubungan dengan sesama merupakan salah satu bentuk ketaqwaan kita kepada Allah SWT. Maka dengan adanya kompetensi sosial, diharapkan guru dapat menjadi jembatan terjalinnya hubungan dengan masyarakat. Khususnya bagi siswa, karena kelak siswa akan terjun ke masyarakat untuk megabdikan dirinya, membantu dan mengamalkan ilmu yang dimiliki kepada masyarakat. Peranan seorang guru dalam menjalankan tugasnya sebagai pelaksana dalam dunia pendidikan, harus dibarengi dengan adanya kepribadian yang baik dan segala kemampuan yang dimilikinya. Baik kemampuan dalam menguasai ilmu pengetahuan maupun kemampuan dalam berinteraksi dengan sesama. Seorang guru akan menjadi sorotan. Guru merupakan tauladan bagi peserta didiknya dalam berperilaku di lingkungan sekolah maupun di lingkungan masyarakat atau kehidupan sehari-hari. Kehidupan dalam bermasyarakat, seorang guru tentunya tidak hanya disorot oleh peserta didiknya saja, namun seluruh masyarakat juga akan menyorotnya. Masyarakat menganggap bahwa seorang guru pastinya adalah seorang yang berilmu, berakhlak mulia, dan seorang yang menginspirasi bagi para peserta didiknya. Jadi, seorang guru haruslah mempertahankan semua anggapan tersebut dan tidak mengecewakan masyarakat yang turut mendukung dalam berjalannya proses pendidikan. Guru merupakan orang tua kedua bagi para peserta didik di lingkungan sekolah. Guru mendapat kepercayaan dari para orang tua peserta didik untuk mendidik dan mengajarkan mereka sesuai dengan apa yang diharapkan dan nantinya bisa menjadi generasi yang membanggakan. 
Hal tersebut menjadi kemampuan guru yang sangat dibutuhkan adalah kompetensi sosial guru. Kompetensi sosial guru ini berkaitan dengan kemampuan guru sebagai bagian dari masyarakat untuk berkomunikasi dan bergaul secara efektif dengan peserta didik, sesama pendidik, orang tua peserta didik, dan masyarakat terhadap perkembangan teknologi informasi dan komunikasi. Kompetensi sosial guru sangat berkaitan dengan cara guru dalam berkomunikasi, berinteraksi, bekerja sama, dan guru mempunyai jiwa yang menyenangkan. (Pingge, H. D.; 2020). Kompetensi sosial guru di dalam artikel ini dibagi menjadi 2 pembahasan, antara lain: 1). Guru dalam Lingkungan Sekolah: Di lingkungan sekolah, seorang guru tentunya akan berinteraksi dengan peserta didik dan sesama guru. Seorang guru harus bisa mencontohkan kepada peserta didik komunikasi yang baik dengan lawan bicara. Di dalam dunia pendidikan, guru merupakan elemen penting dalam pelaksanaan proses pendidikan. Guru adalah penggerak roda pendidikan. Sebagai orang tua kedua bagi peserta didik di lingkungan sekolah, guru memiliki tugas utama yaitu mendidik mereka agar menjadi para penerus bangsa yang membanggakan. Menerapkan interaksi dengan masyarakat sekolah, guru harus mengedepankan etika dan memiliki kompetensi sosial. Dengan peserta didik, penerapan kompetensi sosial dilakukan di dalam kelas dalam pelaksanaan pembelajaran dan juga di area sekolah. Dengan sesama guru dan tenaga pendidik, penerapannya dilakukan di ruang guru dan beberapa acara rapat kerja maupun ketika bertemu di area sekolah. Adanya interaksi dan dilengkapi dengan kompetensi sosial maka hubungan yang terjalin akan semakin baik dan erat. 2). Guru dalam Bermasyarakat: Guru dan masyarakat memiliki hubungan yang sangat erat dalam melaksanakan proses pendidikan. Keduanya memiliki kesamaan dalam hal tanggung jawab dan tujuan. Seorang guru yang berperan sebagai pelaksana teknis dari program sekolah dan masyarakat sebagai pengguna layanan sekolah yang mempunyai tujuan untuk menjadikan peserta didik sebagai generasi yang berkarakter. Menjalankan tanggung jawab tersebut, keduanya harus memiliki hubungan yang baik dan mendukung satu sama lain agar terwujudnya tujuan yang diharapkan. Keberadaan guru di dalam masyarakat sangatlah penting. Karena perilaku yang baik dan kinerja guru dalam berkehidupan dikesehariannya atau dalam bermasyarakat akan dijadikan potret guru. Potret guru merupakan potret bangsa dimasa depan. Untuk mencapai potret guru yang berkualitas tentunya seorang guru harus memiliki kepribadian yang baik, memiliki pengetahuan dan wawasan yang luas, serta berkompeten (Budiana, N. dkk.; 2019) Salah satunya adalah dalam hal berinteraksi serta berkomunikasi yang baik dengan masyarakat, seorang guru harus memiliki kemampuan dan kecakapan perihal tersebut. Seorang guru harus mampu menjaga kepercayaan masyarakat kepadanya tentang kemampuan dalam 
mendidik para generasi bangsa. Dengan kecakapan dalam berinteraksi dan berkomunikasi inilah yang akan menggambarkan betapa berkualitasnya seorang guru.

Berdasarkan penjelasan di atas, tentunya kemampuan komunikasi ini sangatlah penting untuk dimiliki seorang guru dalam menjalankan tugas dan perannya. Tanpa adanya kemampuan komunikasi yang mumpuni, tentu pelaksanaan proses pendidikan dan berkehidupan sehari-hari tidak akan berjalan efektif dan tidak sesuai dengan yang diharapkan. Komunikasi sangat diperlukan dalam berkehidupan di masyarakat. Pentingnya komunikasi bukan hanya sebagai pengantar informasi tapi juga sebagai penghubung silaturahmi antar sesama. Komunikasi dalam Islam sendiri merupakan interaksi yang dilakukan seseorang kepada orang lain dengan perkataan yang baik dan benar. Sepertimana dalam firman Allah SWT dalam QS.Al-Ahzab ayat 70 :

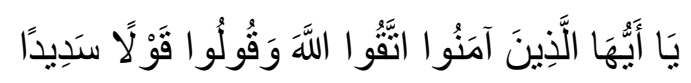

"Hai orang-orang yang beriman, bertakwalah kamu kepada Allah dan katakanlah perkataan yang benar" (Q.S. Al-Ahzab : 70).

Ayat tersebut ditafsirkan oleh Ibnu Katsir bahwa Allah memerintahkan kepada hambahamba-Nya yang beriman agar tetap bertaqwa kepada-Nya dan meneyambah-Nya dengan penyembahan sebagaimana seseorang yang melihat-Nya, dan hendaklah mereka mengucapkan perkataan yang benar, jujur, tidak bengkok, dan tidak pula menyimpang. Dalam berkomunikasi, seorang pendidik atau guru juga harus memiliki kemampuan yang mumpuni, bukan hanya kepada peserta didik tapi juga masyarakat pada umumnya. Menurut (Baharudin, B; 2010) dalam berinteraksi dengan orang lain, guru perlu memperhatikan beberapa etika sesuai yang dijelaskan di dalam Al-Qur'an, antara lain :1. Qaul Baligh: Kata qaul baligh disebutkan di dalam Al-Qur'an hanya sekali yaitu pada surah An-Nisa' ayat 63. Ayat tersebut menjelaskan tentang kebusukan hati orang-orang munafik yang tidak mau bertahkim kepada Rasulullah meski mereka telah bersumpah atas nama Allah, bahwa apa yang mereka lakukan hanya menghendaki kebaikan. Meskipun begitu Rasulullah dilarang untuk menghukum mereka secara fisik, namun cukup dengan memberikan nasehat dan berkata kepada mereka dengan perkataan yang membekas di jiwa mereka. Maka dapat dipahami bahwa qaul baligh merupakan perkataan yang merasuk dan membekas di dalam jiwa. Perkataan baligh ini menurut Al-Isfahani memiliki tiga unsur yakni, bahasa yang digunakan tepat, sesuai dengan apa yang dinginkan, serta isi perkataan mengandung kebenaran. Dalam arti lain perkataan baligh merupakan seseorang yang sedang berbicara secara sengaja dengan maksud ingin menyampaikan pesan dengan tepat supaya dapat 
diterima oleh lawan bicaranya. Hal ini selaras dengan peran seorang guru yang harus berinteraksi dengan masyarakat agar selalu memperhatikan unsur-unsur di atas sehingga pesan yang disampaikan dapat diterima dengan baik. Contohnya, dalam membangun hubungan sosial dengan masyarakat seorang guru harus menggunakan bahasa yang tepat, serta isi perkataannya merupakan suatu kebenaran tanpa ada unsur provokatif sehingga antara guru dengan masyarakat dapat bersama-sama saling memahami, terlebih jika seorang komunikator itu memiliki sifat egois, serakah, dan lain-lain maka akan mengakibatkan adanya pihak yang merasa dirugikan dan komunikasi tidak dapat berjalan secara efektif. 2. Qaul Karim: Kata qaul karim disinggung di dalam Al-Qur'an surah AlIsra' ayat 23. Ayat ini menjelaskan tentang cara berkomunikasi yang baik kepada kedua orang tua terlebih ketika keduanya telah berusia lanjut. Qaul karim dapat dipahami sebagai suatu ucapan yang membuat lawan bicara merasa dihormati dan dimuliakan. Menurut Ibn 'Asyur ucapan yang mulia adalah suatu ucapan yang tidak memojokkan salah satu pihak yang membuat salah seorang tersebut merasa seakan dihina. Misalnya, seorang anak harus selalu memuliakan dan bertutur kata yang baik kepada kedua orangtuanya bahkan ketika orang tuanya telah lanjut usia yang notabene pendengaran, penglihatan, tenaganya sudah lemah. Contoh lain, ketika seorang guru hendak berbicara dengan wali murid maupun masyarakat sekitar yang lebih tua maka harus dengan sopan santun, tidak bermaksud lebih benar dan tidak menyinggung perasaannya. 3. Qaul Maisur: Kata qaul maisur ditemukan di dalam Al-Qur'an surah Al-Isra' ayat 17-28. Ayat tersebut mengajarkan bahwa jikalau kita tidak dapat membantu orang lain karena suatu hal tertentu, maka harus berkata yang lembut, tidak menyinggung persaannya, dan tentunya disertai dengan alasan yang masuk akal. Qaul maisur merupakan perkataan yang lembut, melegakan serta tidak dibuat-buat. Dalam arti lain yakni perkataan yang dikenal baik dan yang biasa digunakan oleh masyarakat sekitar. Sebagai contoh, dapat dilihat dari kisah Luqman saat menasehati anaknya dengan panggilan "yaa bunayya." Hal ini menunjukkan bahwa dalam berkomunikasi perlu adanya rasa kasih sayang serta dapat melegakan hati seorang anak. Komunikasi pendidikan harus tetap disesuaikan dengan usia anak didiknya. Meskipun tujuannya sama, yakni membentuk generasi yang berkarakter dan berakhlak namun cara berkomunikasi dengan anak-anak tentuntunya berbeda dengan cara berkomunikasi dengan anak dewasa. 4. Qaul Ma'ruf: Qaul ma'ruf disebutkan di dalam Al-Qur'an sebanyak empat kali. Qoul ma'ruf diartikan sebagai ucapan yang baik dan ucapannya menancap kedalam hati. Pada prosesnya, suatu ucapan dianggap baik di suatu daerah namun bisa jadi tidak baik di daerah lainnya. Hal ini dapat 
dijadikan acuan bagi seorang guru bahwa perlunya memperhatikan siapa dan dari mana latar belakang orang yang menjadi lawan bicaranya sehingga proses interaksi dapat berjalan dengan baik. Misalnya, ketika seorang guru melakukan interaksi atau komunikasi dengan masyarakat hendaknya perlu menggunakan gaya bahasa yang tepat sesuai dengan adat istiadat atau budaya setempat agar pesan yang disampaikan dapat diterima serta terhindar dari kesalahpahaman. 5. Qaul Layyin: Qaul layyin ditemukan didalam AlQur'an surah Taha ayat 43-44. Ayat tersebut menceritakan tentang kisah Nabi Musa dan Nabi Harun ketika mereka diperintahkan untuk bertemu dengan Raja Fir'aun, yakni supaya mereka berucap kepada Raja Fir'aun dengan ucapan yang layyin. Maksud dari qaul layyin ini adalah ucapan yang mengandung ajakan serta anjuran. Misalnya seseorang berbicara dan berusaha meyakinkan lawan bicaranya bahwa yang disampaikan adalah benar dan masuk akal. Namun yang perlu ditekankan dalam perkataan layyin ini adalah perkataan tersebut tidak berarti kehilangan ketegasan, tetapi maksudnya adalah menyampaikan pesan dengan penuh keyakinan yang akan menyentuh jiwa orang yang menjadi lawan bicaranya. Contohnya jika seorang guru menjelaskan materi kepada peserta didik dengan lemah lembut tetapi masih dalam konteks ketegasan maka materi yang diajarkan akan lebih mudah diterima oleh peserta didik. 6. Qaul Syadid: Qaul syadid disebutkan di dalam al-Qur'an sebanyak dua kali yaitu dalam surah An-Nisa ayat 9 dan Al-Ahzab ayat 70. Secara umum para ulama menafsirkan qaul syadid sebagai ucapan yang jujur, lembut, tepat sasaran, dan mengandung pemuliaan bagi lawan bicaranya. Selain itu, qaul syadid juga memiliki arti sebuah perkataan yang tidak cenderung menyakiti orang lain serta perkataan yang sesuai antara yang sedang diucapkan dan yang terdapat di dalam hati. Pada praktiknya hendaknya semua orang perlu menata dan menjaga lisannya dimanapun dan dengan siapapun lawan bicaranya. (Hakim, H.; 2020). Selain dari beberapa etika di atas, seorang guru juga perlu memperhatikan beberapa prinsip dalam berkomunikasi, seperti : rasa hormat, rasa empati, berbicara dengan jelas sehingga pesan yang disampaikan dapat diterima dengan baik oleh lawan bicara, serta dalam berkomunikasi guru harus membangun sikap rendah hati. (Ahmad, M. A.; 2019)

Berdasarkan pemaparan di atas maka dapat diketahui bahwa keterampilan komunikasi guru sangat berpengaruh terhadap ketercapaian tujuan pembelajaran. Kesuksesan hubungan sosial dan komunikasi antara pendidik dengan peserta didik akan mendukung situasi dan kondisi pembelajaran yang menyenangkan. (Huda, M. N; 2017) Begitupun dengan dimilikinya kompetensi sosial, maka hubungan pendidik dengan masyarakat akan berjalan dengan baik, sehingga jika ada kepentingan dengan orang tua 
peserta didik para pendidik tidak akan mengalami kesulitan. (Muspiroh, Noviyanti; 2016).

Berkaitan dengan hal tersebut, maka perlu adanya strategi atau upaya dalam meningkatkan kompetensi sosial guru di antaranya: 1). Mengembangkan kecerdasan sosial dan sikap komunikatif. Komunikasi adalah salah satu bentuk kecerdasan sosial. Seorang guru memiliki keharusan dalam mengembangkan kecerdasan sosialnya. Karena dengan kecerdasan sosial, hubungan guru dan peserta didik akan lebih baik dan proses pembelajaran pun akan berjalan lancar (Suyitno, L.; 2018). Adapun upaya untuk mengembangkan kecerdasan sosial guru, antara lain: mengadakan diskusi, berani mengambil peran dan mengadakan sosialisasi langsung dengan masyarakat dan lingkungan sekitar. Kecerdasan sosial akan berkembang apabila kegiatan tersebut dilakasanakan secara efektif dan efisien. Sehingga akan tercipta pribadi yang memiliki kepedulian dengan kondisi sosial masyarakat serta mampu memecahkan masalah yang dihadapi oleh seluruh warga sekolah maupun masyarakat sekitar. Menjalankan tugasnya sebagai seorang guru perlu memiliki keterbukaan dengan peserta didik, memunculkan rasa saling menjaga, saling membutuhkan dalam pemenuhan kebutuhannya, saling bermanfaat, saling menghargai perbedaan sehingga berkembang keunikan, kreativitas dan individualisnya (Indrawan , I; 2020b).

Komunikasi merupakan hal yang paling penting dalam kompetensi sosial guru. Dalam proses pembelajaran, sangat diperlukan komunikasi yang efektif antara guru, peserta didik, seluruh warga sekolah, orang tua peserta didik dan juga masyarakat. Maka dalam mengoptimalkan kompetensi sosial, guru harus mempunyai sikap komunikatif. Seorang guru yang komunikatif adalah guru yang dapat menyampaikan informasi kepada penerima informasi baik secara langsung maupun tidak langsung dan juga secara lisan maupun tulisan sehingga penerima informasi mampu menerima apa yang disampaikan dengan baik. Interaksi yang dilakukan sehari-hari oleh guru terhadap peserta didik, warga sekolah, dan juga seluruh masyarakat sekitar merupakan cerminan dari sikap seorang guru yang komunikatif. (Ahmad, M. A.; 2019). 2). Peran kepala sekolah sebagai supervisor dalam pelatihan kompetensi sosial. Kepala sekolah berada di posisi yang paling strategis dalam meningkatkan kompetensi sosial guru dan berperan sebagai supervisor. Kepala sekolah yang berperan sebagai supervisor akan membantu memberikan bimbingan profesional yang mengacu pada upaya dalam meningkatkan kompetensi sosial guru. Proses supervisi ini dilakukan oleh kepala sekolah melalui pengamatan dan penilaian terhadap kinerja guru. Hal ini dilakukan sebagai pengukuran 
sejauh mana kompetensi sosial guru dalam berinteraksi dan bersosialisasi dengan siswa maupun dengan yang lainnya. Maka dengan begitu seorang guru diharapkan dapat melakukan perbaikan untuk mencapai kompetensi sosial yang maksimal serta dapat dikembangkan sampai pada akhir masa pekerjaannya (Yuliana, L; 2007). Jika hasil supervisi kepala sekolah ternyata guru belum memiliki keterampilan komunikasi yang memadai maka kepala sekolah bisa mengirim guru yang bersangkutan untuk mengikuti pelatihan pendukung yang diperlukan.

(Indrawan, I; 2020a) menyatakan bahwa pelatihan-pelatihan yang berkaitan dengan kompetensi sosial misalnya, workshop, seminar, diklat dan lain sebagainya. Beberapa kegiatan tersebut merupakan strategi peningkatan kompetensi sosial yang harus dimiliki seorang guru. Namun yang perlu dipahami sebagai acuan yakni target dan format-format yang dapat mengembangkan kompetensi tersebut seperti; kerja secara berkelompok dan melihat peluang peran dalam kegiatan tersebut, relawan sosial, kedewasaan dalam berelasi, peran sebagai warga, bertoleransi, kepemimpinan, pemberian solusi terhadap konflik, kerjasama dan komunikasi.

\section{KESIMPULAN}

Penjelasan yang dapat disimpulkan dari artikel ini adalah kompetensi sosial memiliki pengertian yaitu kemampuan guru dalam bercakap, berinteraksi atau berkomunikasi dengan peserta didik, guru lainnya, maupun dengan masyarakat sekitar secara efektif dan interaktif. Kompetensi sosial guru dibagi menjadi dua, antara lain: guru dalam lingkungan sekolah dan guru dalam bermasyarakat. Kompetensi sosial guru ini sangat penting untuk dimiliki oleh pendidik atau guru dalam menjalankan tugas dan perannya. Tanpa adanya kompetensi sosial, tentu pelaksanaan proses pendidikan dan berkehidupan sehari-hari tidak akan berjalan efektif dan tidak sesuai dengan yang diharapkan. Maka sudah menjadi suatu keharusan bagi seorang pendidik untuk memiliki kompetensi sosial guru ini agar pendidikan berjalan dengan efektif. Kompetensi sosial terdiri dari kemampuan komunikasi dan juga kemampuan berinteraksi. Kemampuan komunikasi tentunya tak kalah penting juga untuk dimiliki oleh seorang guru dalam menjalankan tugas dan perannya. Tanpa adanya kemampuan komunikasi yang mumpuni, tentu pelaksanaan proses pendidikan dan berkehidupan sehari-hari tidak akan berjalan efektif dan tidak sesuai dengan yang diharapkan. Perlu adanya strategi yang harus dilakukan untuk memaksimalkan upaya peningkatan kompetensi sosial guru. Adapun strategi dalam meningkatkan kompetensi sosial guru di antaranya adalah sebagai berikut: 
mengembangkan kecerdasan sosial dan sikap komunikatif, serta peran kepala sekolah dalam membantu pelatihan kompetensi sosial guru.

Adapun artikel yang kami tulis ini tentunya terdapat kekurangan dan juga kelebihan. Kekurangannya adalah pembahasan yang diuraikan sangat spesifik, sehingga dapat ditemukan pengulangan kalimat diparagraf selanjutnya. Kelebihannya adalah pemilihan bahasa yang sederhana dan pembahasan yang spesifik dapat menjadikan pembaca mudah memahami serta mengambil kesimpulan pada pembahasan. Artikel ini diharapkan mampu mempersiapkan guru menjadi pribadi yang baik dan siap untuk menempatkan dirinya dalam memerankan seorang guru atau pendidik yang baik dalam berkomunikasi dan bersosialisasi.

\section{REFERENSI}

Ahmad, M. A.;. "Komunikasi Sebagai Wujud Kompetensi Sosial Guru di Sekolah." 2019. Ashsiddiqi, M. Hasbi;. "KOMPETENSI SOSIAL GURU DALAM PEMBELAJARAN DAN PENGEMBANGANNYA." TA'DIB, 2012.

Baharudin, B;. "Prinsip-Prinsip Komunikasi dalam Al-qur'an." Ilmu Dakwah: Academic Journal For Homiletic Studies, 2010.

Budiana, N. dkk.;. Etika Profesi Pendidikan Generasi Milenial 4.0. UB Press, 2019.

Chalik, S. A;. "Filsafat Sosial Dalam Al-Qur'an ." Jurnal Tafsere, 2015: 51-68.

Hakim, H.;. "PrinsiPrinsip-Prinsip Komunikasi dan Informasi dalam Prespektif Al-Qur'an Membangun Komunikasi Beradab." Dakwah: Jurnal Kajian Dakwah dan Kemasyarakatan, 2020.

Huda, M. N;. "Peran Kompetensi Sosial Guru dalam Pendidikan." Ta'dibi: Jurnal Manajemen Pendidikan Islam, 2017: 42-62.

Huda, Mohammad Nurul;. "Peran Kompetensi Sosial Guru Dalam Pendidikan." Jurnal Prodi Managemen Pendidikan Islam, 2018: 42-62.

Indrawan , I;. Menjadi Guru PAUD DMIJ Plus Terintegrasi Yang Profesional. Edited by Ravida Dan F.A.Faza'ur. CV.DDOPTLUS Publisher, 2020b.

Indrawan, I;. Guru Profesional. Edited by I.M.Adnan. Lekeisha, 2020a.

Muspiroh, Noviyanti;. "PERAN KOMPETENSI SOSIAL GURU DALAM MENCIPTAKAN EFEKTIFITAS PEMBELAJARAN." 2016. 
Pingge, H. D.;. "Mengajar dan Belajar Menjadi Guru Sekolah Dasar." Edited by Andriyanto. 2020.

Suparman, Oman;. "SUPERVISI KLINISUNTUK MENINGKATKAN KOMPETENSI SOSIAL GURU-GURU DI SD NEGERI HEGARMANAH JALANCAGAK SUBANG." Jurnal Penelitian Guru FKIP Universitas Subang, 2020.

Suyitno, L.; "UPAYA PENINGKATAN KOMPETENSI SOSIAL GURU PPKN DI SMP NEGERI 2 BARAKA KABUPATEN ENREKANG." Jurnal Tomalebbi, 2018: 13-24.

Yuliana, L;. "Peranan Kepala Sekolah Sebagai Supervisor Dalam Kematangan Profesional Guru." Jurnal Manajemen Pendidikan, 2007. 